\title{
AD APPEALS IN THE CONTEXT OF VIRAL ADVERTISING
}

\author{
Maria Petrescu, Barry University, U.S.A. \\ Pradeep K. Korgaonkar, Florida Atlantic University, U.S.A. \\ Tamara F. Mangleburg, Florida Atlantic University, U.S.A. \\ Ann R. Root, Florida Atlantic University, U.S.A.
}

\begin{abstract}
Researchers and practitioners have noted that consumers seem increasingly comfortable with online viral advertising campaigns that encourage individuals to pass along a marketing message to others by Internet or e-mail. World-renowned companies, such as Nike, Budweiser, Ford, GMC, Levi's and De Beers have successfully used viral advertising in social media, including YouTube, Facebook and blogs (Borroff 2000; Morrissey 2008; Rechtin 2009; Solman 2008a, 2008b; Steenburgh, Avery and Dahod 2009; Thompson 2010).
\end{abstract}

Previous research related to the viral process has noted that viral messages need to be funny or intriguing, appeal to the imagination of consumers, related to easy to use or visible products, well targeted, come from a credible source, and are adapted to new technologies (Dobele et al. 2005). The purpose of this paper is to study under what conditions ads become viral, and what are their antecedents and mediators.

Previous advertising research has found that specific ad appeals and executional characteristics of ads influence consumers' attitudes toward the ad (Bagozzi, Gopinath and Nayer 1999; Batra and Ray 1986; MacKenzie, Lutz, and Belch 1986; MacKenzie and Lutz 1989; Tellis 2004). Different advertising execution strategies range from strictly informational to highly emotional (Severn, Belch and Belch 1990). We analyze three of the key ad appeals used in the most successful viral ads currently circulating online: sex, humor, as well as ad informativeness.

In viral studies, researchers found that when product or marketing information comes via an e-mail from a person the consumer knows, the receiver is more likely to pass along this information and forward the e-mail to other consumers (Phelps et al. 2004). We hypothesized that an advertisement received from a known interpersonal source, such as a family member, friend or Facebook contact, will lead to a more positive attitude toward the ad and to a higher chance of forwarding the message, than an advertisement from an unknown source.

In order to test our hypotheses, we used a national consumer sample. We found all three types of ad appeals significant for both attitude toward the ad and viral intentions. We confirmed that humorous and sexual ad appeals positively influence attitude toward the ad and viral intentions. We also found that informative appeals have a positive effect on attitude toward the ad. The results of the statistical analysis, including both viral intentions and the actual viral behavior, confirm that the humorous appeal has the highest importance for viral advertisements and the highest potential when creating ads with the intention to make them viral. Our findings support this previously hypothesized relationship between humor and viral advertising, clarifying the role of humor in the modern viral ads. This represents a step forward for both marketing theory and practice and an empirical confirmation of the importance given to humor by the advertising world.

While we did find a positive relationship between sexual appeal and both attitude toward the ad and viral intentions (and behavior), the sexual ad occupied the third position regarding the strength of its effect, following humor and informative ads. Regarding another characteristics of the ad, its source, the data analyzed did not support our hypotheses that ad source influences attitude toward the ad and viral intentions. This can be due to consumers not finding ads coming from strangers any different from ads originating from friends. Another reason can be related to the manipulations of our experiment and to the fact that in real-life situations consumers might place a higher importance on ad source than in the context of an experiment and online survey.

We confirmed the mediational role of attitude toward the ad in relation to viral intentions, and its positive influence on viral intentions, relating a modern advertising variable related to viral ads to the classical attitude toward the ad. These findings contribute to the theoretical integration of viral intentions in the classical advertising framework, and note the importance of attitude toward the ad for viral behavior.

References available upon request 